\title{
Dinâmicas recentes do agronegócio no Oeste do Pará (Brasil): expansão da soja e estruturação de corredores logísticos
}

\author{
The recent dynamics of agribusiness sector from the west of Pará (Brazil): soybean expansion and logistical corridors
}

Valdemar João Wesz Junior

Universidade Federal da Integração Latino-Americana

(UNILA), Brasil

jwesz@yahoo.com.br

\author{
Karina Kato \\ Programa de Pós-Graduação de Ciências Sociais em \\ Desenvolvimento, Agricultura e Sociedade (CPDA/ \\ UFRRJ), Brasil \\ anirakato@yahoo.com
}

Andréa Rente Leäo

Universidade Federal do Oeste do Pará (UFOPA), Brasil

asgrente@yahoo.com.br

Sandro Augusto Leão

Universidade Federal do Oeste do Pará, (UFOPA), Brasil

sandroleao93@gmail.com

Maria do Socorro Bezerra de Lima

Universidade Federal Fluminense (UFF), Brasil

sblima22@gmail.com

\section{Resumo:}

A expansão da soja no Brasil tem transformado áreas rurais e fomentado a instalação de estruturas logísticas, sobretudo na região amazônica. O objetivo deste artigo é compreender a dinâmica de expansão da soja e de estruturação de corredores logísticos nesta região e seus impactos sobre a mercantilização da terra. A partir de levantamento bibliográfico, dados secundários e da realização de trabalho de campo, se problematiza as formas pelas quais esse processo vem se dando na área do Oeste do Pará, uma das principais e recentes "fronteiras agrícolas e de estruturação de corredores logísticos" no Brasil. Os resultados indicam uma intensa expansão da soja na região, bem como a consolidação deste corredor logístico, fruto de um conjunto de estratégias, nem sempre convergentes, implementadas por diferentes atores sociais.

PalaVras-chaVe: Agronegócio, Corredores Logísticos, Fronteira Agrícola, Amazônia.

\section{ABStraCt:}

The expantion of soybean in Brazil has transformed rural landscapes and fostered the installation of large logistical structures, especially in the Amazon region. The aim of this paper is to understand the dynamics of soybean expansion and the structuring of logistical corridors in this region and its impacts on land commodification. Based on a bibliographic survey and secondary data, and the realization of fieldwork, in this article we seek to problematize the ways in which this process has been taking place in the Western Pará region, one of the main and recent "agricultural borders and structuring of logistical corridors" in Brazil. The results indicate an intense expansion of soy in the region, as well as the consolidation of this logistical corridor, the result of a set of strategies, not always convergent, implemented by different social actors.

KEYwORDS: Agribusiness, Logistical Corridors, Agricultural Borders, Amazon.

\section{Recepción: 15 Febrero 2021 | Aceptación: 12 Mayo 2021 | Publicación: 02 Agosto 2021}




\section{INTRODUÇÃO}

Na virada do século XXI o capitalismo foi marcado por intensas transformações na produção, no comércio mundial e na corrida pela apropriação de recursos naturais em todo o globo, posicionando os alimentos e as terras no centro das agendas de governos e atores privados. A elevada demanda por commodities gerou um processo de "primarização" ${ }^{1}$ do mundo (Apex-Brasil, 2011) e se traduziu em oportunidades e desafios para os países detentores de amplas reservas de recursos naturais e de grandes extensões de terras agricultáveis, como o Brasil. Nesses países observamos o crescimento acelerado das exportações de commodities, o aumento dos investimentos na exploração de recursos, a construção de infraestruturas e a ampliação do poder político e econômico dos setores ligados ao agronegócio e ao extrativismo (Pinto, 2013). Se desde 2013, no mercado internacional, a subida do preço das commodities agrícolas pareceu desacelerar, ${ }^{2}$ isso não tem se revertido no recuo na produção da soja ou na anulação dos projetos logísticos no Brasil.

Uma dimensão importante do atual sistema agroalimentar consiste na construção e consolidação de estruturas que possibilitam o livre fluxo de commodities e mercadorias, que conectam áreas produtivas e mercados globais (White et al., 2012). Esse fenômeno chama atenção para a dimensão espacial do desenvolvimento e para as estruturas logísticas (Nogales, 2014) que materializam uma "nova geografia da extração" (Sassen, 2016, p. 1). Harvey (2003 e 2005) é um dos autores que destaca a importância da logística na anulação do espaço pelo tempo. Nesse processo contínuo o sistema capitalista constrói e destrói espaços e coloca em movimento a fronteira de acumulação capitalista.

A ampliação do cultivo de soja na Amazônia brasileira está conectada com essa dinâmica. A expansão da soja no Brasil teve início na década de 1960, amparada por um grande leque de programas públicos de pesquisa e de melhoramento genético, e por políticas de crédito, de colonização e de regularização fundiária, entre outros. Se até 1960 o Rio Grande do Sul era o único produtor de soja no país, nos anos 1990, embalado pelo desenvolvimento de novas variedades adaptadas a condiçóes climáticas de baixa latitude, o Mato Grosso passou a ser o principal produtor, inaugurando uma nova fase de expansão do cultivo no Cerrado brasileiro (Fernández, 2007; Wesz Jr., 2014). No cenário atual, o Brasil disputa com Estados Unidos o posto de maior produtor mundial de soja e detém um setor do agronegócio com grande poder político e econômico. A soja brasileira é o principal produto de nossa pauta exportadora, com $82 \%$ desse montante destinado para a China em 2018 (Secex, 2020). As autoridades públicas brasileiras e o setor produtivo, contudo, destacam que o Brasil ainda apresenta novas áreas para a expansão da soja.

Esse movimento se fez acompanhado da construção de estruturas logísticas e corredores econômicos, que colocam a fonteira agrícola brasileira em contínuo movimento (Nogales, 2014). Os corredores econômicos, na conjuntura recente de boom das commodities, reforçam narrativas de desenvolvimento pautadas nas commodities e dão materialidade a estruturas e instituições que avançam na mercantilização da terra. Esse reposicionamento dos territórios na divisão global de funções coloca-os na mira dos investimentos diretos estrangeiros, e, ao mesmo tempo, levam os territórios a uma crescente especialização na produção e no escoamento de commodities. Os corredores têm operado, portanto, como um importante vetor da expansão da soja e de abertura de novas fronteiras agrícolas. ${ }^{3}$

O Estado neoliberal se alinha à economia global e aos interesses corporativos globais, facilitando a endogeneização do global no local. Adicionalmente, tem trabalhado na mudança do aparato governamental (marcos regulatórios e instituições) na direção de uma maior mercantilização da terra e dos recursos naturais. A incorporação das terras aos circuitos globais, não raro, resulta na crescente expulsão de pessoas do campo, no crescimento da pobreza e de doenças, na superexploração do trabalho e na privatização de recursos naturais (Sassen, 2013). Não obstante que alguns autores tenham apontado oportunidades atreladas a esses movimentos (Cotula et al., 2009), as experiências recentes sugerem que esses processos têm se dado de uma maneira bastante complexa e, em se tratando de desenvolvimento humano e social, com resultados bastante questionáveis (White et al., 2012; Borras et al., 2014; Levien, 2014). 
Sendo assim, a análise das conexões entre a expansão das monoculturas, a estruturação dos corredores logísticos e a mercantilização da terra e recursos naturais são questões atuais que seguem abertas. Em nossa opinião, é a partir dos territórios e dos corredores específicos que essas experiências devem ser olhadas, examinadas e problematizadas. Por isso, chegamos ao Oeste do Pará, na Amazônia brasileira. A região tem se consolidado como uma das novas e mais movimentadas "fronteiras agrícolas e de estruturação de corredores logísticos" no país, ocupando o espaço entre as estratégias do agronegócio brasileiro e os interesses dos mercados internacionais. A fim de atender à demanda chinesa com menores custos, os produtores do norte do Mato Grosso (principal região produtora de soja no Brasil), têm buscado novas rotas logísticas que lhes permitam transportar a soja de forma mais eficiente, rápida e barata. A grande distância dos principais centros produtores de soja no norte do Mato Grosso até os portos do Sul e Sudeste (principais exportadores de soja) tem figurado como um grande "gargalo" para a ampliação da produção da região. É nesse contexto que os produtores têm apostado nos caminhos do "Arco Norte" e na criação de infraestruturas como hidrelétricas, hidrovias, rodovias, ferrovia e portos. O Oeste do Pará emerge como um dos principais canais logísticos para "encurtar os caminhos para a China". A dimensão estratégica da nova rota fica clara nos dados do último anuário da Confederação Nacional do Transporte: as exportações de Mato Grosso via Arco Norte saltaram de $13 \%$ para $43 \%$ entre 2013 e 2017 (CNT, 2018).

O objetivo deste artigo é compreender a dinâmica de expansão da soja e de estruturação de corredores logísticos nesta região, e seus impactos sobre a mercantilização da terra. Este trabalho está alicerçado em um levantamento bibliográfico nacional e internacional acerca dos temas da pesquisa, bem como na sistematização de dados secundários e cartográficos. Além disso, em novembro de 2017, foi realizado um trabalho de campo nos municípios paraenses de Santarém, Belterra, Mojuí dos Campos e Itaituba, que resultou em 12 entrevistas com atores chaves, representantes de diferentes setores, como produtores rurais, empresas, Sindicato Rural (Sirsan), Sindicato dos Trabalhadores e Trabalhadoras Rurais (STTR), secretaria municipal da agricultura, secretaria municipal de planejamento, Empresa de Assistência Técnica e Extensão Rural (Emater), Secretaria de Meio Ambiente e Sustentabilidade (Semas), Instituto Nacional de Colonização e Reforma Agrária (Incra) e Movimento dos Atingindo por Barragens (MAB).

\section{A EXPANSÃo DA SOJA E DA LOGÍ́STICA DE GRÃos No NORTE do BrASIL}

Ao longo da segunda metade do século XX e início do século XXI, a produção da soja apresentou um intenso processo de expansão no Brasil, cuja área plantada saltou de 1,3 para 36,9 milhões de hectares entre 1970 e 2020, e ocupou neste último ano uma superfície superior a $50 \%$ dos cultivos temporários (Conab, 2020). O Brasil é hoje o maior produtor e exportador mundial de soja em grão, superando os Estados Unidos (USDA, 2020). Em 2018, o Brasil exportou cerca de 33 bilhões de dólares FOB de soja, que passou a ser o principal produto da pauta de exportações do país (14\%), com um crescimento de $29 \%$ com relação ao montante exportado no ano anterior (Secex, 2020). Esse é um resultado surpreendente se considerarmos que, em 2000, a soja ocupava o terceiro lugar na pauta de exportações brasileiras, com um montante de 2 bilhões de dólares ( $4 \%$ do total). O complexo soja (que além do grão inclui os derivados, como óleo e farelo) respondeu por $17 \%$ das exportações totais em 2018. Chama a atenção a participação da China nos destinos das exportações brasileiras, que entre 2000 e 2018 saltou de $15 \%$ para 82 \% (Secex, 2020).

$\mathrm{O}$ crescimento da demanda chinesa, nesse sentido, tem operado como um importante driver impulsionador da produção de soja (e de suas estruturas logísticas) no país, renovando os interesses de investimentos (e atraindo novos atores) e reforçando rotas logísticas pelo norte do país. O aumento nas exportações chinesas ao longo dos últimos anos teve como contrapartida o crescimento da produção de soja no Brasil, o que reforçou dinâmicas de avanço da fronteira agrícola em direção aos Cerrados e à Amazônia (centro-norte do país), como podemos observar nos mapas abaixo (Figura 1). 
O intenso processo de espacialização da produção de soja no Brasil está ilustrado na Figura 1, que mostra a evolução da área plantada com o grão nas últimas décadas por microrregião. Ao longo deste período ficam evidentes dois processos correlatos: expansão do cultivo para novas regiões (novas "fronteiras") e a consolidação em áreas mais "tradicionais". No que se refere à expansão, demonstra-se um claro avanço do cultivo sobre as áreas de cerrado nos estados do Centro-Oeste, Nordeste e Minas Gerais, além da região amazônica (sobretudo, sul do Pará, no Tocantins, em Rondônia, no Amapá e em Roraima). Em paralelo também ocorreu a concentração da área cultivada no Sul do país. Nos últimos 18 anos, nas regióes mais "tradicionais" de produção de soja, no Sul do país, onde o cultivo até pouco tempo encontrava-se estagnado, observou-se uma nova fase de expansão e intensificação da produção. $\mathrm{O}$ crescimento mais acelerado da produção de soja, contudo, não foi observado nas tradicionais regiões produtoras, mas em novas áreas (em especial na Amazônia brasileira), num processo contínuo de incorporação de superfícies à cadeia da soja.

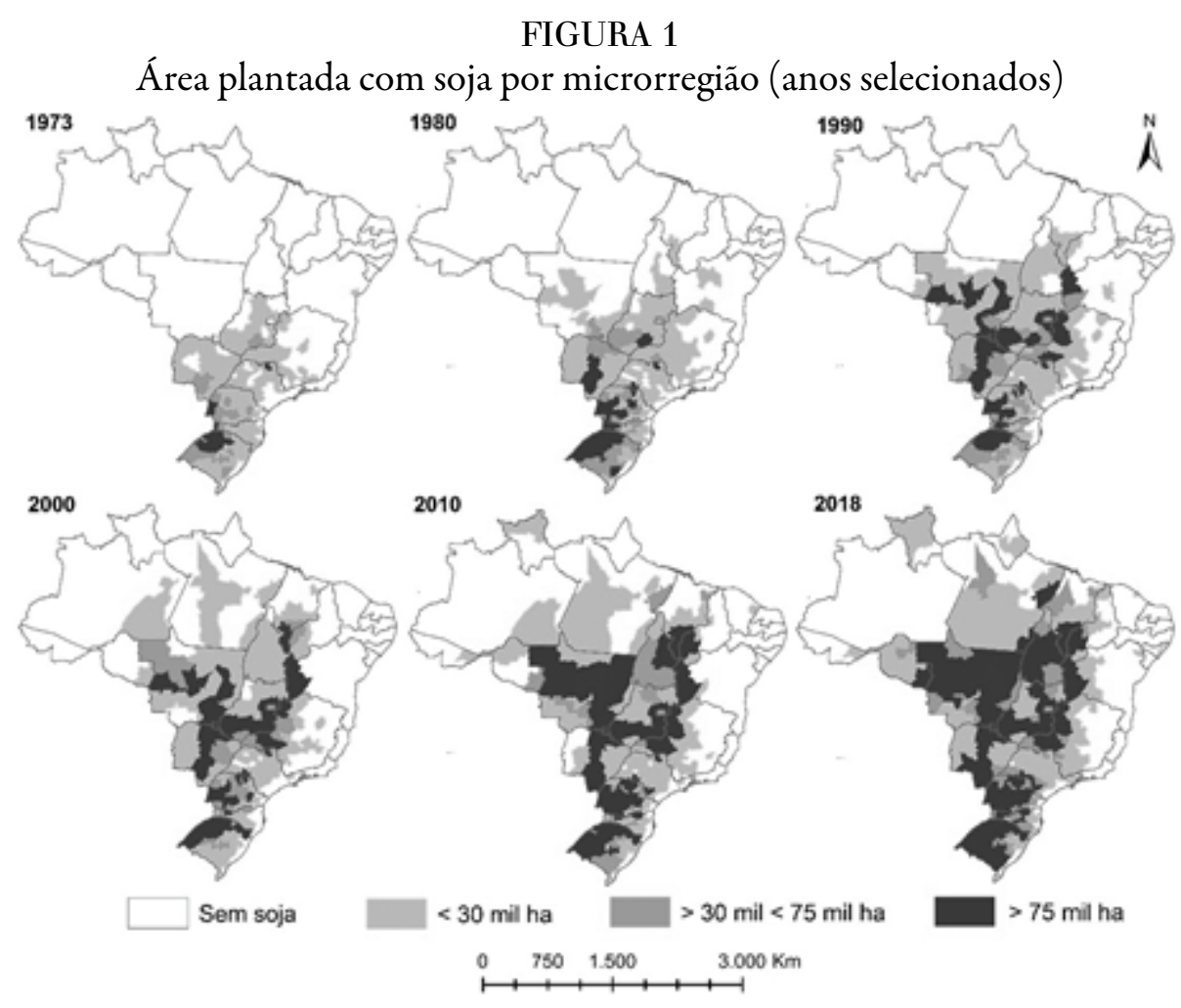

Fonte: IBGE - Produção Agrícola Municipal (2020). Elaborado pelo Grupo de Estudos sobre Mudanças Sociais, Agronegócio e Políticas Públicas (GEMAP/UFRRJ).

Segundo dados da Produção Agrícola Municipal (IBGE, 2020), o Mato Grosso segue sendo, de longe, o estado com maiores extensões de terras dedicadas à soja (bem como o maior produtor), totalizando $27 \%$ da área plantada no Brasil, seguido do Rio Grande do Sul e do Paraná. Mas foi na região Norte em que se observou a maior ampliação da área plantada com soja entre 2000 e 2018, alcançando $2.385 \%$ de crescimento (salto de 73 mil para 1,9 milhões de hectares). Em 2018 a região Norte respondeu por $5 \%$ da área plantada com soja (contra $0,5 \%$ em 2000), proveniente principalmente do Tocantins ( $48 \%$ da superfície regional), Pará (31\%) e Rondônia (18\%), além de Roraima (2\%) e Amapá (1\%). Quadro muito semelhante foi observado na produção, de modo que a região Norte do Brasil apresentou um crescimento de $2830 \%$ na quantidade de soja produzida. Esse montante não se repete em nenhuma outra região do país (que estão no patamar de um crescimento de $200 \%$ ).

Diante da demanda crescente dos mercados internacionais por soja, em particular da China, o setor produtivo tem apostado em três estratégias principais (executadas de forma simultânea e não excludente) que 
vêm integrando o Oeste do Pará aos circuitos globais da soja. Os maiores e mais capitalizados produtores do Mato Grosso têm investido crescentemente no uso de insumos industrializados (adubos e fertilizantes) e na adoção de novas tecnologias, a exemplo da agricultura de precisão, a fim de elevar a produtividade (Buainain, Bonacelli \& Mendes, 2015; Vieira Filho \& Gasques, 2016). Isso tem imposto aos produtores nas principais regiões um elevado padrão de competitividade e um custo crescente de produção por conta do encarecimento de insumos, maquinário, combustíveis etc., e, em especial, das melhores terras para o plantio. Com isso, produtores menores e menos capitalizados têm sido "expulsos" dessas áreas. Outra estratégia tem sido a migração desses produtores menores para novas áreas em busca de terras mais baratas e da possibilidade de expandir a área plantada, o que colocou a fronteira agrícola em movimento acelerado (Fernández, 2007; Wesz Jr., 2014). Como destino destaca-se o Pará, em particular as mesorregiões do Sudeste, Sudoeste e do Baixo Amazonas (Lima, 2008; Sauer \& Pietrafesa, 2013; Leão, 2017), incluindo nossa área de estudo nesse artigo (o Oeste do Pará). Destaca-se também áreas de cerrado dos estados que conformam o MATOPIBA (Maranhão, Tocantins, Piauí e Bahia) (Heredia, Palmeira \& Leite, 2010; Favereto et al., 2019). A terceira estratégia tem sido a busca, principalmente dos produtores mais consolidados do Centro-Oeste (com destaque para os do Mato Grosso), por novas e mais baratas vias de escoamento da soja para os mercados internacionais (em especial para os mercados asiáticos), procurando encurtar as distâncias até os portos e reduzir os custos com a logística de seus produtos. Boa parte dessas vias logísticas convergem para o Arco Norte, na região norte do país.

É nessa conjuntura que a produção de soja vem ganhando cada vez mais peso na economia paraense: seja por meio da expansão das áreas destinadas à produção de soja, seja pelo crescimento dos projetos de portos, estradas, hidrovias e ferrovias que são idealizados e direcionados para a região. Isso conforma uma dinâmica regional que se retroalimenta: a realização e a expectativa de novas estruturas logísticas fomenta a produção nas suas áreas de influência, o que, por sua vez, justifica a pressão por melhores estruturas logísticas (Leão, 2017; Sauer, 2018). Consolida-se assim, no presente, uma nova dinâmica resultante da projeção (e instalação) de novas rotas logísticas em direção ao Norte. Essas cruzam o Oeste do Pará e interligam o território paraense com os mercados globais e com as regiões mais tradicionais de produção de grãos do Mato Grosso, num acelerado processo de anulação do espaço pelo tempo, nas palavras de Harvey (2005). As dinâmicas socioeconômicas e territoriais observadas nesta região em torno da cadeia da soja, logo, são impulsionadas por forças externas: pelo comportamento dos mercados internacionais e pela maneira como essa região é incorporada nos portfólios de investimentos produtivos e em infraestrutura do agronegócio.

\section{Os caminhos da soja no Oeste do Pará: produção e logística}

No final dos anos 1990 e início do século XXI se conformaram três grandes áreas de produção de soja no Pará, como colocado pela Embrapa (2004): 1) Polo Nordeste - formado pelos municípios de Paragominas, Ipixuna, Ulianópolis e Dom Elizeu; 2) Polo Sul/Sudeste - municípios de Redenção, Marabá, Conceição do Araguaia, Santa Maria das Barreiras e Pau; 3) Polo Oeste - municípios de Santarém, Novo Progresso, Belterra, Aveiro, Rurópolis, Placas, Uruará, Itaituiba, Trairão. De acordo com dados do IBGE (2020), é justamente nessa primeira área cunhada pela Embrapa como Polo Nordeste, que se concentram as maiores extensões de terras destinadas à plantação de soja. Paragominas (com $28 \%$ do total das terras do Pará destinadas à soja em 2018), Dom Eliseu (com 16\%) e Ulianópolis (com $11 \%$ ), juntos conformam 50 \% das áreas do estado e têm demonstrado um crescimento sensível nos últimos anos (cerca de $50 \%$ entre 2015 e 2018). O crescimento mais acelerado, contudo, vem se dando nas outras áreas cunhadas pela Embrapa, a saber, Polo Sul/Sudeste e Polo Oeste, não obstante a participação das mesmas no total de terras destinadas à soja do estado ainda seja pequena.

Municípios do Polo Oeste do Pará, nossa região de estudo, vem apresentando crescimento significativo nas lavouras de soja (Leão, 2017). Segundo dados da Produção Agrícola Municipal (IBGE, 2020), o Oeste 
do Pará teve como marco inicial da produção de soja o ano de 1997, com uma área plantada de 50 hectares em Santarém. Desde 2002, observamos uma tendência de crescimento contínuo na superfície plantada com soja, que alcançou em 200535 mil hectares. Entre 2006 e 2013 houve certa estabilidade na área, mantendose próxima dos $30 \mathrm{mil} \mathrm{ha,} \mathrm{tendo} \mathrm{crescido} \mathrm{para} 40 \mathrm{mil} \mathrm{ha} \mathrm{nas} \mathrm{três} \mathrm{safras} \mathrm{seguintes.} \mathrm{O}$ ano de 2017 marcou um novo movimento de expansão, chegando a uma superfície cultivada de $55 \mathrm{mil} \mathrm{ha,} \mathrm{o} \mathrm{que} \mathrm{constituiu} \mathrm{um} \mathrm{novo}$ marco na região do Planalto Santareno ${ }^{4}$ (Figura 2).

FIGURA 2

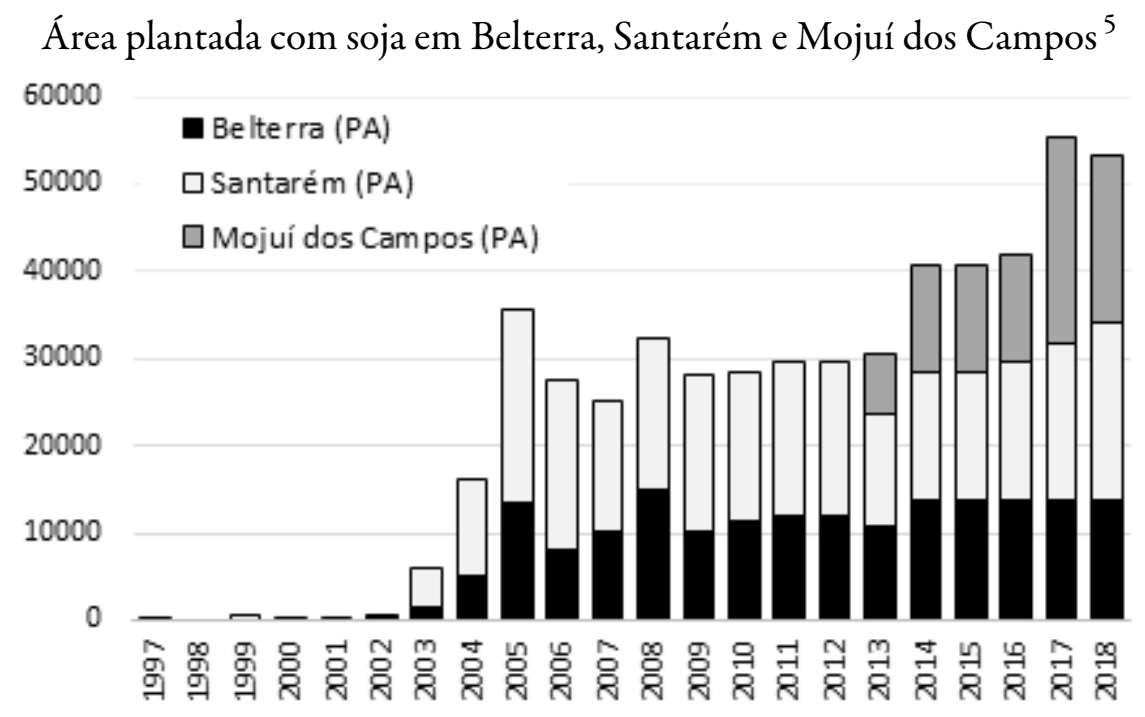

Fonte: IBGE - Produção Agrícola Municipal (2020).

Na Figura 3 é possível perceber as transformações no uso do solo no Planalto Santareno. Em 1985 predominavam as áreas de floresta (em verde). Em 1995 é visivel a ampliação da pastagem (em amarelo) em áreas que até então detinham vegetação nativa. Em 2005 já se percebe o aumento das áreas de pastagem e o surgmimento de lavouras temporárias (em rosa), ausentes até o início dos anos 2000. No período seguinte estas áreas crescem, chegando em 2018 com grande amplitude, destinadas sobretudo ao cultivo da soja.

Os produtores entrevistados no SIRSAN ilustraram essas diferentes etapas da soja no Planalto Santareno em suas falas. Para eles, o início dos anos 2000 foi o período de chegada de um conjunto de produtores "sulistas" na região. ${ }^{6}$ Antes de se estabelecerem em Santarém, esses produtores produziam soja no Mato Grosso (Rondonópolis/Campo Verde, Primavera do Leste/Lucas do Rio Verde, Nova Mutum e Sorriso). Para eles, a decisão de migração "mais ao Norte" passava pelo próprio contexto mato-grossense, que, como sintetizou um dos entrevistados, "concentrou e expulsou os outros para a fronteira”. Ao comentar sobre a realidade no Mato Grosso, outro produtor afirmou que lá era preciso ter no mínimo 1.500 hectares para tornar a produção viável, devido aos altos custos e aos imperativos de alta produtividade (e competitividade) da região. Diante desse cenário, os produtores optaram por vender suas terras e comprar uma área maior na fronteira. 
FIGURA 3

Uso do solo no Planalto Santareno

1985

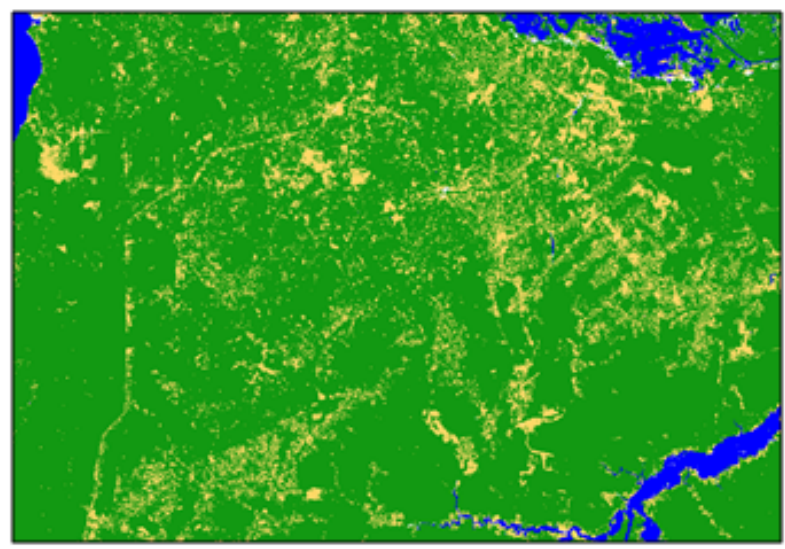

2005

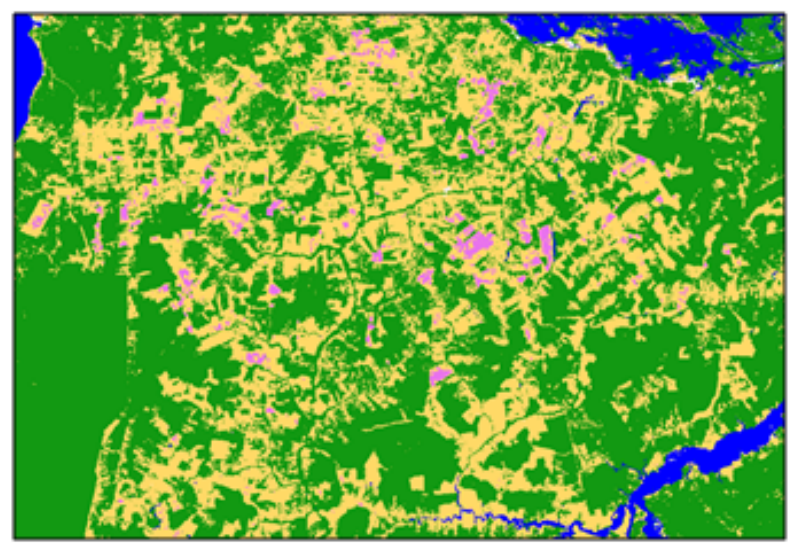

1995

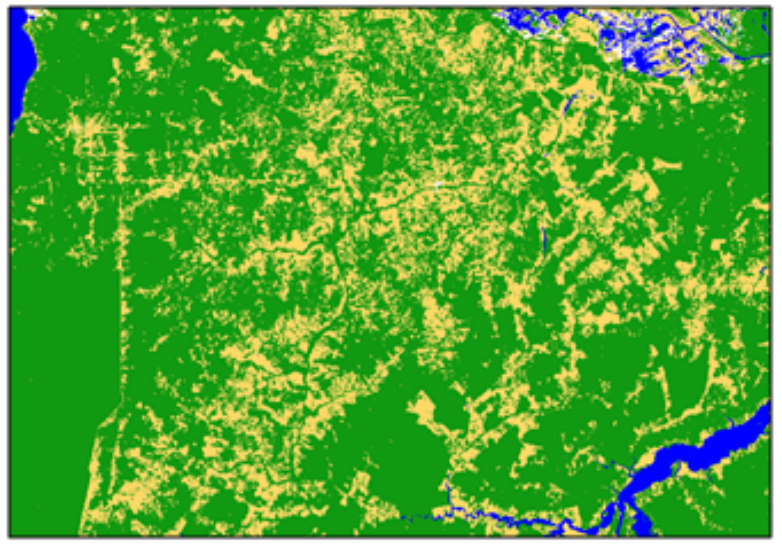

2018

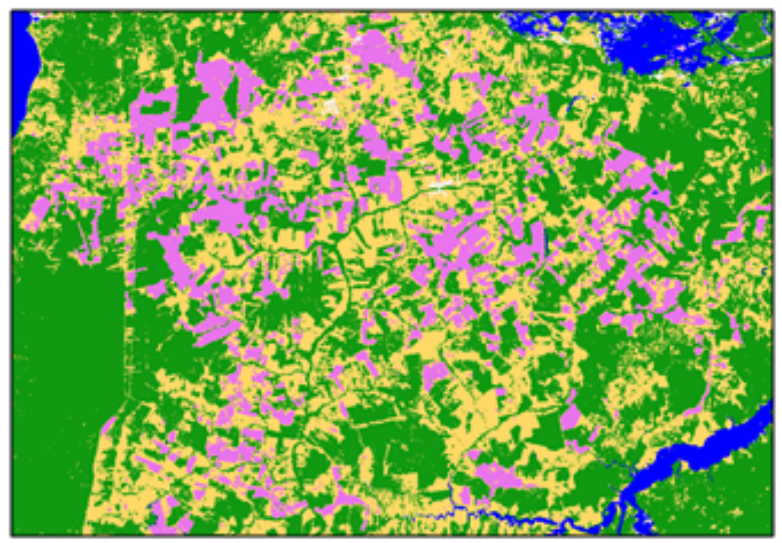

Fonte: Mapbiomas (2020).

Um representante da Secretaria da Agricultura de Santarém chamou atenção para as ações da Prefeitura de Ruy Correia (1993-1996, PMDB), que iniciou um estudo pela Companhia de Pesquisa de Recursos Minerais (CPRM) com diagnóstico das potencialidades do solo, ${ }^{7}$ e do governo de Lira Maia (na época do PFL), que lançou o Zoneamento Agroecológico de Santarém, e que realizou o mapeamento das áreas para o cultivo da soja em Santarém. Tal estudo confirmava que o Planalto Santareno era apto para a produção da oleaginosa: apresentava solos planos e profundos, com lençol freático a 70 metros, tendo sol o ano inteiro e chuvas bem distribuídas (não demandando irrigação). Essas condições, segundo o representante da prefeitura, permitiriam a produção da safra, safrinha e terceira safra.

O representante da Secretaria de Agricultura do município aponta que esses mesmos argumentos foram usados pelo então prefeito (Lira Maia) para divulgar a potencialidade agrícola de Santarém nas principais áreas de produção do país e para atrair produtores das regiões consolidadas, como Mato Grosso. Buscavam, sobretudo, produtores mecanizados que pudessem trazer a soja para o Planalto Santareno. Para o representante da Prefeitura, "esse foi o arranque" para a expansão da soja na região. Segundo os produtores, as áreas do Planalto Santareno que hoje possuem soja em Santarém, Belterra e Mojuí dos Campos, eram ocupadas antes pela pecuária. Entretanto, estudos realizados durante o período de expansão da soja no Planalto santareno apontam que, além das áreas de pecuária, houve a substituição de áreas antes ocupadas por pequena produção familiar, que produzia alimentos para o mercado local (Valbuena \& Cohenca, 2006; Carvalho \& Tura, 2006). 
Os anos de 1997-2004/5, segundo relatos, foram o auge da produção de soja, com a chegada de grande número de produtores na região. Segundo dados da entrevista no SIRSAN, "estavam ali cerca de 300-400 produtores”. Entre 2003 e 2005 a euforia em torno da produção de soja na região pautava-se, principalmente, pelo elevado preço do grão (em real e em dólar) e pelo funcionamento do terminal graneleiro da Cargill em Santarém, recém-inaugurado (2003), que garantia o escoamento. Num momento posterior, a produção de soja se estabilizou na região. Os produtores destacam um período de crise, que conjugou a descapitalização dos produtores, a queda na área de produção de soja e arroz, e o aumento da pressão ambiental em torno do desmatamento. Entre 2013 e 2014, a soja voltou a crescer e chegou a 10 mil hectares na região, mantendose no patamar de 40 mil hectares em 2015 e 2016. O representante da Prefeitura de Santarém (Secretaria de Agricultura) comentou que a região hoje "tem 600 mil hectares propícios para agricultura, mais de $60 \%$ mecanizáveis”. Importante lembrar que, além das condições edafoclimáticas, no Oeste Paraense, o preço da terra é muito mais barato do que em outras regiões mais consolidadas (FNP, 2014).

Ao longo dos anos, o Planalto Santareno sofreu um processo de concentração da produção de soja, pois dos 300-400 produtores entre 2003 e 2005 restaram 120 produtores/famílias em 2017. Segundo o presidente do SIRSAN, $20 \%$ desses produtores tem mais de 1.000 hectares, sendo que o maior produtor da região tem 3.200 hectares. Três produtores entrevistados no SIRSAN confirmaram terem aumentado suas áreas ao longo dos anos na região: foram comprando áreas do entorno de sua propriedade.

A área com a oleaginosa cresceu $31 \%$ na região entre 2016 e 2017, alcançando o valor histórico de 55 mil hectares totais em Belterra, Santarém e Mojuí dos Campos, o qual tem se mantido em 2018 (Figura 2). Um dos produtores entrevistados iniciou o cultivo com 12 hectares de soja, em 2000, e atualmente produz 100 hectares. Mas esse mesmo produtor aponta que teria mais de 1.000 ha de terra própria, grande parte dedicada à pecuária. Outro produtor afirma que comprou 860 hectares para o cultivo de soja em 2005 e em 2012 ampliou a área própria, alcançando 1.200 hectares, dos quais 1.000 foram destinados ao cultivo de soja. Ele também arrenda mais 500 hectares para a produção do grão. O terceiro produtor entrevistado conta que, em 2001, comprou 200 hectares de áreas de pasto. Hoje planta soja em 900 hectares, sendo metade própria e metade arrendada. Essas dinâmicas refletem a concentração da estrutura fundiária da região, comprovadas pelos dados dos Censos Agropecuários de 2006 e de 2017: para além da propriedade da terra, esses produtores exercem o controle da terra por meio do arrendamento (IBGE, 2020).

$\mathrm{O}$ discurso dos produtores se assenta ora na produtividade e na modernização da produção, ora na sustentabilidade, o que reflete a importância central que a questão ambiental adquire no atual contexto e a necessidade desses produtores em apropriarem-se desse debate. De modo geral, a tecnologia e a sustentabilidade aparecem associadas na narrativa que reafirma que a tecnologia permitiria um uso mais racional dos recursos e um menor impacto ambiental se comparado com a agricultura tradicional de pequena escala. Segundo relatos, os produtores não fazem agricultura de cinquenta anos atrás; usam áreas de pastagem degradadas e entram com agricultura de precisão. Seus discursos valorizam a tecnologia como uma aliada no tratamento das questões ambientais: usam drones, usam imagens por satélite, usam biomassa. Destacam o desenvolvimento de duas tecnologias: o Geographic Information Systems (GIS), que é um sistema de armazenamento de dados de posições geográficas com os seus atributos (concentração de nutrientes, porcentagem de infestação de pragas e doenças e produção) e o Global Positioning System (GPS), que provê informação sobre o posicionamento de equipamentos em coordenadas de latitude, longitude e altitude. Segundo os produtores, são eles, portanto, que colaboram com a preservação ambiental (se contrapondo à agricultura mais tradicional que seria "menos sustentável").

A pressão ambiental (em particular, as denúncias de desmatamento na Amazônia e a visibilidade internacional) teve, também, um papel central no arrefecimento e na reconfiguração da expansão da soja na região, obrigando-os a buscar soluções que possibilitassem combinar a produção com os imperativos ambientais. Para eles, havia 186 ONGs em Santarém no início dos anos 2000 que questionavam os impactos 
do porto da Cargill, do asfaltamento da BR-163 e da expansão da soja, sobretudo na sua relação com o desmatamento: "Até o Bill Gates veio para cá" (referindo-se à Fundação Bill e Melinda Gates).

Em 2006, a Moratória da Soja ${ }^{8}$ determinou que a Cargill deixasse de comprar soja (e automaticamente de financiar) que viesse de terra desmatada do bioma Amazônia (Leão, 2017). A partir desse momento, a questão ambiental passou a ser determinante no contexto regional, o que obrigou os produtores a se adaptarem a esses novos critérios buscando soluções que liberassem a exportação do grão. Destacaram o papel da The Nature Conservancy (TNC) com o desenvolvimento da “Soja Mais Sustentável”. Com esse projeto, a TNC e o Estado monitoravam as áreas e, em caso de constatação de desmatamento irregular, o produtor ficava impossibilitado de entregar a soja na Cargill. Originou dessa iniciativa o projeto piloto que criou o Cadastro Ambiental Rural (CAR), que depois foi nacionalizado com o Código Florestal como uma política pública ambiental. Desta forma, crescentemente, o CAR passou a ser utilizado pelos produtores, pelo governo (local, regional e nacional), e pelas tradings como "certificação ambiental". 9 Segundo esses produtores, a pressão ambiental os obrigou a criar instrumentos tecnológicos e de políticas públicas para lidar com essas pressões de maneira a seguir vendendo a soja no mercado internacional.

O representante da Emater destaca que a recente redução do apoio à agricultura familiar no Brasil contribuiu com a expansão da soja no Planalto Santareno, ao deixar os agricultores familiares mais vulneráveis. Se no início dos anos 2000, junto com as políticas de promoção da produção de commodities, observou-se a ampliação das políticas públicas voltadas para a agricultura familiar, possibilitando a atuação da Emater junto a esses produtores e a diversificação da produção no meio rural Santarem, nos tempos recentes, mudanças no quadro político provocaram a redução desse apoio à agricultura familiar (cujo marco foi a destituição do Ministério do Desenvolvimento Agrário em 2016), paralisando ações de apoio a esses produtores. Esse quadro de maior vulnerabilidade e de desmonte de políticas públicas de apoio, associado a um maior aquecimento do mercado de terras na região impulsionado pela chegada dos "sojeiros", levou esses produtores a, num limite, venderem suas terras e saírem do campo.

A expansão da estrutura logística na região, por sua vez, vem marcando o ritmo da expansão da soja na região. A instalação do porto da Cargill em Santarém, em 2003, marcou o "arranque" da soja na região ao instituir um novo canal de comercialização da soja produzida no Oeste do Pará. Posteriormente, os planos em torno do Corredor Tapajós, com a retomada do debate do asfaltamento e da duplicação da BR-163, a partir de 2013, e a instalação e licenciamento de mais de 15 portos privados em Itaituba foram fatores fundamentais para o crescimento da soja no Planalto Santareno. A possibilidade de "produzir dentro e em cima do porto", facilitava o escoamento para os mercados internacionais e incentivava os produtores a migrarem para o Planalto Santareno. Além de facilitar o escoamento das safras regionais e a importação de insumos, as perspectivas em torno do corredor econômico fomentavam a valorização das terras próximas à rodovia (BR-163). Recentemente, as perspectivas em torno da construção de mais um porto em Santarém (Porto de Maicá) têm multiplicado a atratividade do Planalto Santareno (nas margens da BR 163 e da PA Curuá Una). Um dos produtores comentou que, ao produzir a soja próximo ao porto, o custo do transporte se torna muito baixo e aumenta o preço pago pela produção, implicando em maiores margens ao produtor. "Se a logística não foi até o Mato Grosso, eu vim até o porto". Segundo esses produtores, os portos e estradas são importantes não apenas para escoar a soja produzida, mas para baratear a importação de adubo químico: "As carretas vão com a soja para o porto e retornam com o adubo químico que vem da Argélia".

Os gargalos na logística para escoamento da soja, para esses produtores, é "um problema nacional", uma "questão pública" que deve ser assumida também pelo Estado. Em seu discurso, os produtores reforçam que o custo de produção, que inclui o custo logístico elevado, prejudicaria a competitividade da soja brasileira no mercado internacional, o que se constituiria como um problema do país (e não dos produtores) sobre o qual o governo deveria agir. Ainda segundo esses produtores, de nada adiantaria eles "fazerem o dever de casa" e alcançarem uma elevada produtividade "dentro da porteira" se o governo não agir na redução dos custos. 
Seguindo essa lógica, no auge do boom das commodities, os corredores econômicos foram retomados nas estratégias de promoção do crescimento econômico dos governos dos países em desenvolvimento. A expansão da logística e as estratégias de anulação do espaço pelo tempo (Harvey, 2005) têm operado como alavancas para a transformação da agricultura tradicional (de subsistência), em particular na América Latina e África (Smalley, 2017; Nogales, 2014; Hope \& Cox, 2015). Segundo seus defensores, ao possibilitar um transporte mais eficiente em termos de tempo e de custos econômicos essas estruturas possibilitariam o ganho de produtividade, o aumento da competitividade, a atração de capitais, a dinamização das atividades econômicas e o combate à pobreza rural (Nogales, 2014). Por outro lado, muitos casos têm demonstrado que a expansão da agricultura em larga escala tem sido acompanhada da expulsão de pequenos produtores e comunidades tradicionais, de danos ambientais, da valorização e da especulação com as terras, e da conformação de estruturas fundiárias mais desiguais (Kato et al.; 2020).

As estruturas logísticas envolvem múltiplos atores, governamentais e privados. O Estado, em suas múltiplas instâncias, tem um papel central na sua viabilização. Ele promove o investimento público, acessa e direciona financiamentos, traça rotas e mapas, flexibiliza as legislações nacionais, garante a segurança jurídica para os investimentos, cria o consenso em torno dos corredores e as narrativas legitimadoras de sua construção, entre outras. Multinacionais e corporações, por sua vez, são os principais atores a apoiarem os corredores, tendo em vista a importância da logística em seus negócios (Nogales, 2014). Sua materialização, contudo, envolve múltiplos conflitos e disputas em torno de diferentes rotas de escoamento que podem favorecer ou não os interesses de determinados atores (públicos ou privados) em detrimento de outros, bem como abranger diferentes regiões.

No Brasil, a construção de estruturas logísticas voltadas para a conexão de territórios de extração de recursos naturais com mercados internacionais, pelo Estado, não é algo novo. Não obstante, a visão de corredores logísticos como promotores do desenvolvimento regional e nacional ganhou força e novas roupagens em tempos recentes. A partir da década de 1990, no Brasil, observamos o crescimento da ideia dos eixos de integração e desenvolvimento (Tavares, 2016; Vianna et al., 2006; Becker, 1999) que consistiam no fomento a investimentos estruturantes em faixas de infraestrutura econômica, visando ao aumento de fluxos de bens e serviços entre regiões produtoras e mercados externos, e ao fortalecimento de vocações e potencialidades. Esses planejamentos foram cristalizados no programa de investimento do governo chamado "Brasil em Ação" (1996-1999), no plano plurianual que lhe deu seguimento, denominado “Avança, Brasil” (2000-2004), e, mais recentemente, no Programa de Aceleração do Crescimento (PAC) e no Programa de Parcerias de Investimento. Nestes dois últimos, encontravam-se projetos de pavimentação da BR-163 (até Miritituba) e a construção da Ferrovia Ferrogrão, que ligará Sinop (MT) à Miritituba (PA), e que é um dos principais trajetos para escoamento da soja do Centro-Oeste do país, um dos seus principais centros produtores (no corredor Arco Norte).

\section{Mudanças regulatórias no Oeste do Pará}

O aumento da produção de soja no Planalto Santareno nos tempos recentes tem sido impulsionado, também, por mudanças regulatórias que destacam o papel do Estado. Um aspecto importante, nesse sentido, diz respeito as mudanças na legislação de regularização fundiária com o Programa Terra Legal (e aprofundado com a Lei 13.465 , de 2009). A questão ambiental foi outro campo cujas mudanças regulatórias favoreceram os interesses dos produtores. O CAR tem facilitado a regularização ambiental das áreas de produção. No Oeste do Pará, segundo técnicos da Secretaria Estadual de Meio Ambiente (Semas), as regularizações fundiária e ambiental têm se reforçado para viabilizar o aumento das áreas produtivas na região. Atores do setor produtivo têm utilizado o CAR em processos de regularização fundiária e como documento certificador de conformidade com a legislação ambiental junto às empresas. 
O Programa Terra Legal reforçou a dinâmica de crescimento da soja na região. O Programa tinha como objetivo a destinação e a regularização fundiária das terras públicas federais na Amazônia Legal (em torno de 67,4 milhões de hectares de terras arrecadadas sem destinação), facilitando a regularização de terras públicas na Amazônia (ocupadas até junho de 2008), com dimensão de até 1.500 hectares, com dispensa de licitação. Propriedades com tamanho até um módulo fiscal teriam a titulação gratuita e aquelas de um a quatro módulos fiscais teriam valores abaixo do valor de mercado. O Terra Legal incidia também sobre a regularização fundiária de terras públicas da União, em áreas urbanas e de expansão urbana, transferindo sua regularização para o domínio da administração municipal (definidas pelo Plano Diretor).

As frustrações com a lentidão no processo de regularização fundiária na Amazônia com o Programa Terra Legal levaram à criação do Grupo Executivo Intergovernamental para a Regularização Fundiária na Amazônia Legal (GEI) e a uma crescente flexibilização nos seus critérios e procedimentos (nos documentos comprobatórios necessários para regularização fundiária, aceleração de procedimentos etc.). Em 2017, o Tribunal de Contas das União (TCU) realizou uma auditoria no Programa Terra Legal Amazônia e constatou inúmeros problemas, relacionados a: a) Baixo índice de atingimento das metas e objetivos propostos; b) existência de beneficiários que não atendiam aos requisitos do programa, além de falhas formais em processos de titulação; c) valor cobrado no Programa Terra Legal na titulação de imóveis rurais era desproporcional ao valor pago pelo público alvo, e d) não adoção de providências pelo MDA para a retomada das áreas nos casos de descumprimento das cláusulas resolutivas e de indeferimento.

Segundo dados do Incra (Canuto, s/d), o Terra Legal atuaria sobre cerca de 55 milhões de hectares. Ainda que o programa tenha enfrentado inúmeras dificuldades, a partir de 2013 seus resultados aceleraram: em 2012 foram 2.379 títulos emitidos; em 2013, 4.615; em 2014, 10.272, e em 2015, 2.992 (Canuto, s/d). Só em 2014 foram destina dos 9.928.655 hectares no Oeste do Pará, boa parte das glebas públicas federais próximas à área da BR-163 (Canuto, s/d). Na região em estudo a maior parte dos imóveis georreferenciados pelo Programa se localizava no Planalto Santareno, em áreas propícias à produção de soja. Em 2017, com a promulgação da Lei 13.465, o Programa Terra Legal foi nacionalizado e seus limites ampliados para 2.500 hectares.

Segundo entrevistas, os produtores do Planalto Santareno têm adotado a estratégia de fragmentação de suas propriedades de maneira a facilitar a regularização de terras. O entrevistado da Semas aponta:

Eu não sei se orientados pelo Sindicato Rural, ou qual a orientação, mas a maioria das áreas são bem pequenas: 25, 30, 40, 50 hectares. E são muitas áreas repartidas: o pai, o filho, o tio, o primo, o vô, a vó.

O entrevistado suspeita que esta prática de desagregação das terras entre familiares é motivada, em particular, para facilitar o processo de regularização (e tornar mais barato) e agilizar os licenciamentos. Lembramos que, em relação ao Terra Legal, ter área inferior a um módulo fiscal ( 75 ha) permitiria a gratuidade na emissão do título na regularização. Adicionalmente, na faixa de um a quatro módulos fiscais (300 ha), além de ser menos burocrático (por dispensar a vistoria in loco para constatar a situação real do imóvel), estabelece-se um valor menor para titulação, que varia entre $10 \%$ e $30 \%$ do valor mínimo da terra nua. Nesse sentido, a divisão das terras entre familiares, formando imóveis menores, poderia ser uma estratégia dos produtores para fins de enquadramento no programa de regularização e para reduzir a burocracia e o custo de titulação da propriedade, percebida pelo técnico da Semas.

Segundo o técnico da Semas, a divisão das terras também tem outra motivação:

Por terem unidades menores, tem o benefício da reserva legal do novo código.

(...) O módulo rural em Santarém é 75 hectares, então 300 hectares é quatro módulos. Então em Santarém até 300 hectares ele pode ficar sem reserva [se havia desmatado até 2007], porque ele se enquadra nesse benefício. Mais que isso tem que ter reserva.

Por exemplo, se um proprietário tem uma área de 600 hectares, sendo metade de mata e o restante de cultivo, ele pode desmembrá-la em duas, destinando uma à produção. Como é inferior a 4 módulos, ele é dispensado de área de preservação (no caso de ter sido desmatado antes de 2007, dado a anistia oferecida 
pelo novo Código Florestal) nesse imóvel. No outro imóvel, de mata, ele ainda pode desmatar mais $20 \%$ (60 hectares) sem descumprir a lei vigente. Para o entrevistado da Semas é difícil captar essas estratégias se o produtor registra o imóvel em nome de um terceiro. Segundo o técnico: "O que a gente pode verificar é a questão da limitação física: tem que ter um acero, uma cerca, para não caracterizar que é um único imóvel”.

A nacionalização do CAR com o Código Florestal, facilitando a regularização ambiental, foi outro importante instrumento para garantir a segurança jurídica dos investimentos na Amazônia Legal. O CAR, um instrumento autodeclaratório e com pouca (ou quase nenhuma) fiscalização tem sido utilizado como certificação para a regularização ambiental. A literatura especializada, contudo, tem levantado algumas limitações do CAR: a) Fragilidade jurídica e técnica associada às medidas do Novo Código Florestal; b) as constantes prorrogações dos prazos e atrasos; c) cadastros e registros que incidem sobre a terra e a eliminação do conflito fundiário, e, d) o CAR não prevê nenhum tipo de responsabilidade técnica sobre as informações registradas (Soares Filho et al., 2014; Guidotti, et al., 2017).

O CAR acaba por certificar que o estabelecimento está cumprindo com as legislações ambientais sem haver de fato uma fiscalização, baseando-se tão somente na declaração do proprietário por meio de um cadastro digital. A Cargill, por exemplo, só compra soja de propriedades que tenham o CAR e o utiliza como certificado ambiental. Ao mesmo tempo, numa área como a Amazônia Legal, aonde os direitos de propriedade não estão definidos e totalmente atribuídos, o CAR tem sido utilizado como documento que atesta a ocupação no território, o que facilita a regularização fundiária de terras griladas e o acesso a variadas políticas públicas (como o crédito, programas de habitação rural, entre outros). Em Santarém o CAR está a cargo da SEMAS, que também é responsável pela implementação de ações de apoio a licenciamento. $\mathrm{O}$ técnico entrevistado nos chamou atenção para a falta de infraestrutura e de recursos que a SEMAS enfrenta, o que fragilizaria bastante sua ação de fiscalização.

A Semas, responsável pela análise e validação de todos os CAR emitidos, no momento em que realizamos o trabalho de campo estava descentralizando a análise do CAR, repassando-a para os municípios. Só no Oeste do Pará haveria 184.169 cadastros (no Pará são 333.508). Importante mencionar, no entanto, que no Pará, há uma paralisia nas análises e validações do CAR (análise de documentações, visitas etc.), tendo em vista o número excessivo de cadastros e a pouca infraestrutura à disposição dos municípios. A análise desses cadastros, logo, tem se dado basicamente por cruzamentos do próprio sistema (identificação de sobreposições).

O técnico da Semas reconhece os desvios na mobilização do CAR pelos produtores rurais. Em alguns casos, o CAR vem sendo utilizado como documento comprobatório da posse e, logo, como peça nos processos de regularização fundiária no Pará (em especial no Planalto Santareno), facilitando a regularização e a grilagem de terras devolutas e públicas.

\section{DiNÂMICAS E DISPUTAS EM TORNO DOS CORREDORES LOGÍSTICOS DA SOJA}

O intenso movimento de expansão da soja na direção Norte do país tem colocado na agenda pública e privada a construção de corredores logísticos para escoamento da produção. $O$ projeto com maior visibilidade no Brasil, hoje em dia, é o "Arco Norte", que inclui muitas obras de infraestruturas, como hidrelétricas, hidrovias, rodovias, ferrovia e portos, cortando os estados de Rondônia, Amazonas, Amapá, Pará e Maranhão, e que pretende ampliar os canais logísticos no Norte e no Nordeste do país (CNT, 2018).

No Arco Norte, identificamos duas principais rotas logísticas de grãos. A primeira tem se dado por meio do transporte rodoviário, em especial pela BR 163, que liga o Norte do Mato Grosso (Sinop, Lucas do Rio Verde e Sorriso) até Itaituba no Pará, onde inúmeras Estações de Transbordo de Cargas (ETC) privados embarcam a soja em barcaças (até 30 mil toneladas) que seguem, por transporte hidroviário, até o porto de Barcarena ou Santarém. A Bunge/Amaggi foram as primeiras empresas a se instalarem no distrito de Miritituba, município de Itaituba, em 2014, e hoje possuem uma das maiores estações de transbordo na região. A Companhia Norte 
de Navegação e Portos (Cianport), detida pela Fiagril e pela Agrosoja, se instalou em 2016. Atualmente operam também portos em Miritituba a Hidrovias do Brasil, a ADM, a Caramuru e a Cargill. A Louis Dreyfus iniciou a construção do seu porto em 2018. A multiplicação dos portos e a valorização dos terrenos de Miritituba à margem do Tapajós sugerem como essa rota tem se configurado numa importante saída para os produtores do Norte do Mato Grosso em direção aos mercados internacionais. Segundo a Federasul, a rota logística pelo Arco Norte é 34\% mais barata que o trajeto de Sorriso a Santos (SP). Atualmente o trajeto segue pela BR-163, mas há a expectativa no futuro da construção de uma ferrovia entre Lucas do Rio Verde ou Sinop e Miritituba (Ferrogrão, com 1.100 quilômetros). O trecho foi parte integrante do Programa de Parcerias de Investimentos (PPI) do governo Temer e consta nas estratégias empresariais das principais tradings do setor (Amaggi, ADM, Bunge, Cargill, Dreyfus).

A segunda rota, com foco em Santarém, tem se configurado como a principal estratégia e demanda dos produtores do Planalto Santareno. Desde 2003, a Cargill opera na região um terminal fluvial de granéis sólidos, que exporta soja produzida no Mato Grosso (de rodovia até Porto Velho ou Miritituba, e, depois, por barcaças) e no Planalto Santareno (Belterra, Mojuí dos Campos, Santarém). Atualmente, diante das margens de lucro cada vez mais espremidas pelos custos, os produtores do Planalto têm reivindicado a construção de um segundo porto em Santarém (no bairro de Maicá), de modo a diversificar os canais de escoamento e venda da soja.

As corporações empresariais que atuam no corredor logístico ao norte do Brasil apresentam estratégias de mercado que se assemelham no geral. Ao mesmo tempo em que atuam como concorrentes no processo de consolidação das estruturas logísticas, que envolvem o transporte e o transbordo de cargas de grãos, estabelecem alianças pontuais, ações compartilhadas e iniciativas de cooperação para diminuir os custos das suas operações, como a criação de joint ventures e a divisão de cargas em navios graneleiros de exportação, conforme foi possível apurar na pesquisa de campo em Itaituba.

No caso da atuação da Cargill, ela vem realizando altíssimos investimento em em estruturas de escoamento e armazenamento da soja no Norte do país (Leão, 2017). Além disso, a Cargill vem implementando estratégias de diferenciação de produtos, com vistas a se tornar líder em nutrição no mundo (Valentim, 2018).

A Bunge e a Amaggi ampliaram a parceria iniciada em 2014, quando formaram a joint venture Unitapajós (Navegações Unidas Tapajós) voltada para a navegação na hidrovia Tapajós-Amazonas. A transação, prevê a aquisição, por parte da Amaggi, de 50 \% da Estação de Transbordo, em Miritituba, e do Terminal Portuário, em Barcarena, ativos que formam o complexo portuário Miritituba-Barcarena (PA) da Bunge, permitindo assim uma gestão compartilhada de todas as ações locais. Essa estratégia se alinha ao processo de otimização dos ativos da Bunge em busca de parcerias estratégicas para capturar oportunidades de crescimento.

A consolidação do Corredor Tapajós permanece atualmente como uma das principais prioridades do governo de Jair Bolsonaro e uma das mais importantes pautas políticas do setor do agronegócio nacional em suas reivindicações. Os produtores rurais mato-grossenses têm sinalizado interesse em investir no projeto. Além do projeto de acesso à Miritituba via a Ferrogrão, está no papel a construção da hidrovia Tapajós-Teles Pires (Figura 4).

Durante o trabalho de campo presenciamos em Santarém uma grande movimentação do SIRSAN, das universidades locais (em particular a Ufopa) e dos movimentos sociais e organizações da sociedade civil, com as discussões e audiências públicas acerca do novo plano diretor do município. $\mathrm{Na}$ ocasião o sindicato chegou a preparar camisetas e convites que foram encaminhados a todos os seus associados, incentivando-os a participar de forma organizada das audiências do Plano Diretor. Os relatos coletados em campo mostraram que a principal preocupação dos produtores de soja era alterar o plano diretor da cidade de maneira a garantir a instalação do Porto do Maicá, às margens do Rio Amazonas, pela Empresa Brasileira de Portos de Santarém (Embraps). 


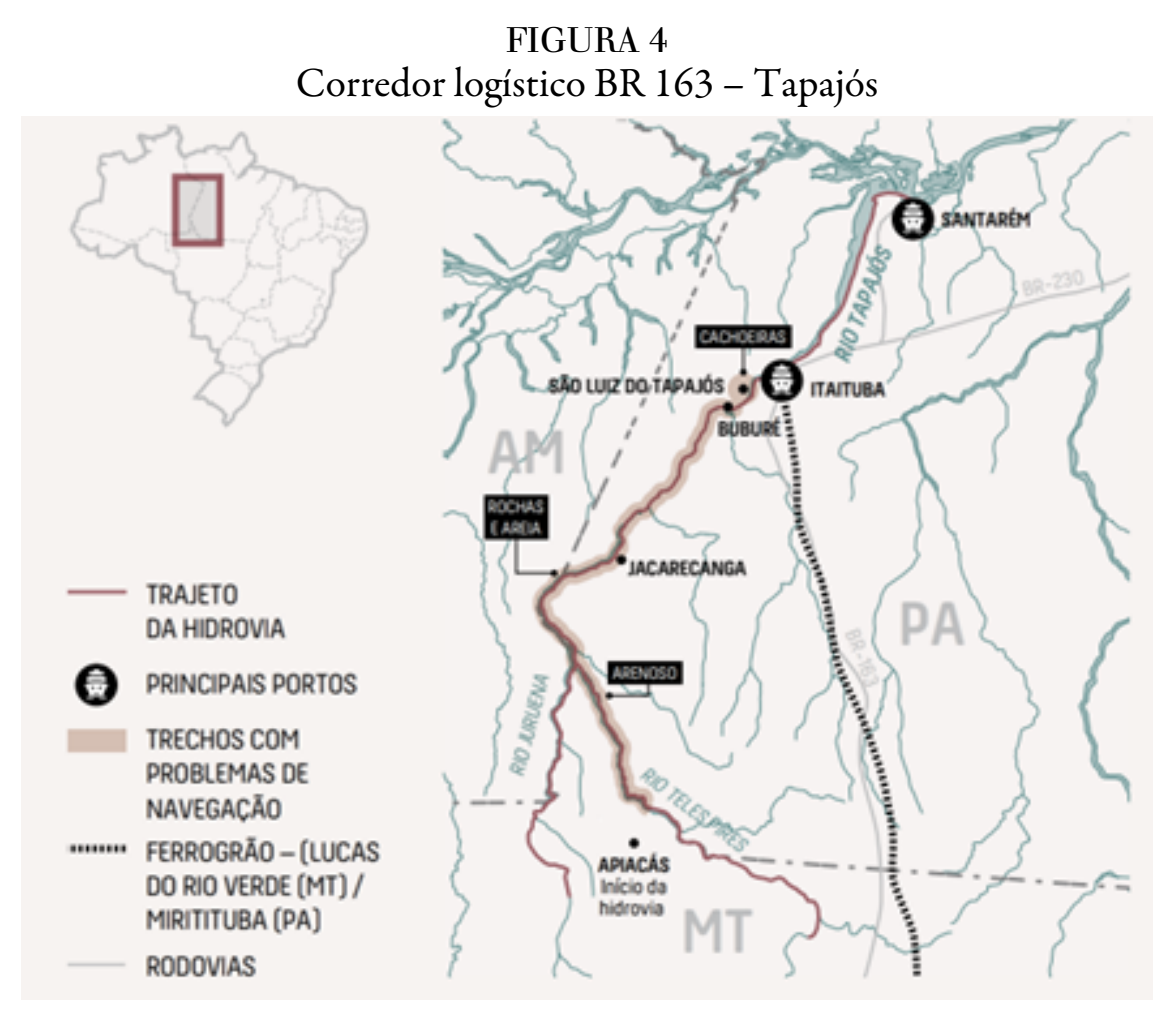

Fonte: Aguiar (2017).

A região de instalação do porto, área de proteção permanente, era ocupada por sete comunidades quilombolas (Marapemã, Saracura, Maria Valentina, Bom Jardim, Murumurutuba, Tiningu e Mururu). Para o Sindicato, o estabelecimento dessa área como expansão urbana no plano diretor facilitaria a regularização das áreas pelo município e maior rapidez na instalação do porto tendo em vista as normas do Terra Legal. O projeto de construção de um porto no lago Maicá não era novo, e já tinha sido rechaçado em dois planos diretores participativos de Santarém (em 2006 e 2017) (Scannavino, 2018). Não obstante, em dezembro de 2018, a fim de dar segurança jurídica aos empreendimentos privados planejados para a área do Maicá, a Câmara dos Vereadores de Santarém apresentou uma proposta de emenda para adequação do artigo 142 do Plano Diretor do Município de Santarém, definindo a área do Maicá como Zona Portuária. Segundo matérias de jornal (Vieira, 2018), a emenda foi resultado da discussão com participação de segmentos produtivos da sociedade, como SIRSAN, Câmara de Dirigentes e Lojistas (CDL), Associação Comercial e Empresarial de Santarém (ACES), entre outros. O porto é estratégico para os planos dos produtores de soja na região, na medida em que representaria uma outra alternativa de escoamento da produção, quebrando o monopsônio do porto da Cargill. O novo porto, portanto, melhoraria as condições de negociação e de exportação de soja para os produtores locais.

Esses projetos, ao aterrizarem nos territórios, mobilizam um amplo leque de atores regionais e locais (econômicos, políticos), transformam as paisagens rurais e urbanas, alteram as dinâmicas produtivas dos territórios, e, não raro, geram muitos impactos socioambientais. Os Estados tem, em suas distintas escalas, dedicado apoio por meio de diferentes práticas e instrumentos: ao selecionar os "espaços" em que serão implementados por meio de projetos de atração de investimentos; ao construir e reforçar a narrativa de "espaços vazios" que precisam de dinâmicas exógenas para se desenvolverem; ao flexibilizarem as legislações trabalhistas e ambientais (incluindo as omissões na aplicação de leis que poderiam barrar esses investimentos); ao implementarem e desenharem projetos de investimentos públicos em logística e fomentarem parcerias público-privadas; ao concederem isenções fiscais; ao atuarem na desapropriação de áreas de seus antigos ocupantes e ao destinarem terras públicas para esses novos projetos, entre outras (Levien, 2014; Sassen, 2016). 
$\mathrm{Na}$ ampliação da produção de soja no Planalto Santareno, e, em particular, na prospecção e legalização das terras para instalação dos projetos logísticos, destacamos um grupo diversificado de atores locais que atuam junto aos atores privados: imobiliárias urbanas e rurais, grileiros, agentes de cartórios, autoridades públicas, elites locais e até funcionários de bancos (que concedem créditos e possibilitam a utilização da terra como garantia em múltiplas transações). Em Itaituba, alguns entrevistados citaram a importância das imobiliárias, em particular, a Kananda Negócios, que é uma empresa que atua no Pará desde 2009 com expertise na legalização de imóveis e loteamentos. O secretário de Planejamento de Itaituba alega que essas imobiliárias rurais compram terras de pequenos posseiros motivadas pelas perspectivas de valorização futura. Elas chegam antes e negociam as terras em bloco, antecipando a chegada dos investidores, inflacionando o preço das terras e aguardando o melhor momento para vendê-las. A especulação com terras torna-se assim o seu principal negócio.

No que concerne, em especial, à instalação dos projetos logísticos, o Estado tem desempenhado um papel central, seja pela sua presença e ação estratégica, seja pela sua ausência ou omissão proposital. A ação estratégia do Estado dá-se na abertura de espaço para as empresas do agronegócio e de logística e na construção de um ambiente institucional seguro para essas empresas. Sua agência pode ser percebida nos processos de regularização fundiária e de regularização ambiental, que são ora agilizados, ora bloqueados, de acordo com os interesses em jogo. Segundo o representante do Movimento dos Atingidos por Barragens $(\mathrm{MAB})$, a regularização fundiária sempre constituiu um problema na realização dos direitos dos posseiros, que ocupavam a terra sem nunca alcançarem, de fato, a propriedade. Os investidores por detrás dos projetos logísticos, contudo, não parecem enfrentar essas dificuldades. As autoridades estatais trabalham de diversas formas para agilizar a regularização desses projetos. Assim, a situação de fragilidade em que vivem os posseiros da região facilita e favorece a instalação das empresas, na medida em que a ausência dos títulos de propriedade por parte dos posseiros e situação irregular do imóvel desvaloriza a terra e intimida os posseiros, que acabam vendendo e repassando suas terras com maior facilidade para os grandes produtores e investidores. A agilidade com que essas empresas conseguem legalizar suas transações contrasta com a fragilidade e as dificuldades enfrentadas pelos posseiros na região.

As distintas rotas logísticas planejadas, por sua vez, têm aumentado a disputa entre os diferentes municípios para sediar os empreendimentos, numa eterna "chantagem locacional". As autoridades de Santarém apontam que o município perdeu muitas oportunidades e vantagens econômicas com a instalação das estações de transbordo em Itaituba. Ao mesmo tempoo, reforçam que precisam fazer mais concessões para garantir que o Porto do Maicá saia do papel o mais rápido possível com isenções fiscais e flexibilização de regulações. Seria uma forma de "compensar" as oportunidades "perdidas" nas etapas anteriores de instalação do Corredor do Tapajós. Itaituba, por sua vez, diz que, não obstante as promessas feitas na ocasião de chegada dos portos privados, poucos benefícios se concretizaram.

A complexidade da estrutura fundiária no Pará (o famoso "caos" fundiário), que faz com que boa parte da área de Itaituba seja federal, dificulta o reconhecimento das diferentes jurisdições no que concerne à terra, e tem criado disputas entre diferentes órgãs públicos e "atropelado" os governos locais. Segundo o secretário de Planejamento de Itaituba, a chegada dos portos gerou uma enorme expectativa para o poder público municipal, mas o que fica no município derivado das operações desses empreendimentos é muito pouco.

Não obstante a instalação dos portos em Miritituba, segundo o entrevistado, todas as empresas acabaram instalando seus escritórios em Novo Progresso, que é o município que acaba arrecadando as receitas e os benefícios econômicos dos empreendimentos. Ademais, como boa parte das áreas em que os portos foram instalados eram áreas federais, as negociações das empresas têm se dado diretamente com o Incra, sem participação dos governos locais, que não conseguem nem ao menos negociar suas contrapartidas. Segundo o secretário de Itaituba, o município tem permanecido com os impactos negativos dos novos empreendimentos (atração desordenada de pessoas, poluição, congestionamento e modificação da paisagem 
do rio com barcaças, entre outros), mas tido pouquíssima chance ou oportunidade para negociar com as empresas ações socioambientais.

Diante disso, o governo municipal vem trabalhando na esperança de ampliar a légua patrimonial municipal com o objetivo de garantir às autoridades municipais a regulação dos portos. Há expectativa de que, no futuro próximo, quando ainda se planeja a instalação de cerca de $26-28$ portos na região, a Prefeitura consiga negociar diretamente com as empresas seus interesses. Segundo o entrevistado, hoje, as mercadorias passam por Miritituba em direção aos mercados globais, mas o que acaba ficando no município são os impactos sociais e ambientais gerados por esses empreendimentos. Percebe-se nas áreas no entorno do Rio Tapajós o aumento da especulação com terras e uma acentuada corrida, que resulta em dinâmicas de privatização e concentração da estrutura fundiária, e a substituição, nas águas do rio, das canoas e barcos de pescadores artesanais por barcaças cheias de soja que tranquilamente cortam o rio em direção ao mercado chinês.

\section{CONSIDERAÇÕES FINAIS}

No Oeste do Pará percebemos o impacto direto da expansão da soja desde o final dos anos 1990, o que tem colocado em marcha um processo crescente de privatização e concentração de terras, de conversão de terras em áreas de plantio de soja, no desmatamento de áreas de floresta remanescentes, e na pressão sobre terras de agricultores familiares, assentamentos e de povos e comunidades tradicionais. Um dos drivers da expansão das monoculturas na região tem sido a instalação de infraestruturas logísticas, que se refletem nas inúmeras barcaças cheias de soja que cruzam o rio Tapajós. Esses dois processos, contudo, olhados de forma integrada, revelam a rápida conversão do Oeste do Pará numa zona especializada na exportação de commodities,cuja velocidade é ditada pelo mercado internacional. Constitui, portanto, duas dinâmicas articuladas que se retroalimentam: a expansão e a consolidação da produção de soja em áreas consolidadas (como no Mato Grosso) "expulsam” produtores para novas regiões (empurrando a pecuária e colocando a fronteira em movimento) e fomentam a construção de complexas estruturas logísticas; esses corredores, adicionalmente, e a expectativa de valorização que engendram, fomentam a valorização das terras, a expansão e a crescente consolidação do Planalto Santareno como fronteira agrícola. A "nova fronteira”, portanto, está conectada com a velocidade da produção nos centros mais consolidados e capitalizados de produção de soja e com o ritmo de crescimento da demanda dos mercados internacionais.

A pesquisa de campo realizada nos permitiu perceber aspectos muito ricos sobre a forma como esses processos se dão na prática e desde os territórios em que se desenrolam. Mais do que um processo linear e determinista, a instalação do Corredor Logístico do Tapajós tem envolvido a articulação de múltiplos atores, públicos e privados. Neste processo complexo, o Estado, em especial no plano federal, tem desempenhado o papel de principal articulador junto aos atores privados. Governos locais, por sua vez, têm procurado crescentemente se reposicionar e ganhar maior poder de barganha frente aos atores privados que chegam na região, o que não raro tem deflagrado a crescente competição entre municípios para abrigar esses projetos logísticos e produtivos.

A principal consequência desses investimentos tem sido a corrida por terras na região: seja para fins produtivos (ampliação da fronteira agrícola), para fins logísticos, ou para a especulação (jogando com a expectativa de valorização do mercado de terras na região). De um lado, essa conjuntura tem se materializado na conformação de um amplo e aquecido mercado de terras impulsionado pelas iniciativas do Estado, visando à aceleração da regularização fundiária na região e incentivando a crescente privatização e mercantilização das terras públicas. Acompanhando essa dinâmica, observamos a maior profissionalização no processo de identificação e regularização das terras, com a cresente atuação de imobiliárias rurais que antecipam a chegada dos investimentos e lucram com a rápida valorização das terras. De outro, posseiros, pequenos produtores, e povos e comunidades tradicionais perdem suas terras ou são pressionados a vender suas propriedades e a 
buscar oportunidades em áreas menos valorizadas, ao mesmo tempo que pescadores artesanais perdem acesso aos rios, cujo ritmo passa a ser ditado pelo escoamento da soja.

Com apoio do Estado, por meio da implementação de mudanças regulatórias, observa-se uma crescente apropriação pelo agronegócio das críticas e restrições ambientais que até então constituíram um obstáculo à expansão da produção de commodities na Amazônia. Com narrativas que enfatizam a tecnologia como instrumento de garantia da sustentabilidade, os produtores de soja vêm se projetando como preservadores da natureza enquanto atribuem a degradação ambiental aos pequenos produtores e à agricultura tradicional.

Por fim, chama atenção o poder que esses investimentos têm de transformar o espaço. A chegada da soja e das infraestruturas logísticas não imprime mudanças drásticas apenas no meio rural, mas vem crescentemente definindo as dinâmicas e o perfil das áreas urbanas. Chama atenção e permanece como uma questão a ser investigada o poder que essas cadeias produtivas e estruturas logísticas em torno das commodities têm em redirecionar os territórios e transformar as paisagens rurais e urbanas à sua semelhança.

\section{REFERÊNCIAS BIBLIOGRÁFICAS}

Aguiar, D. (2017). A geopolitica de infraestrutura da China na América do Sul. um estudo a partir do caso do Tapajós na Amazônia brasileira. Rio de Janeiro: Fase, Actionaid.

Apex-Brasil. (2011). As exportações brasileiras e os ciclos de commodities: tendências recentes e perspectivas. Brasília: APEX.

Becker, B. K. (1999). Eixos de Integração e Desenvolvimento e a Amazônia. Revista Território, 4(6), 29-42.

Borras Jr., S. M., Franco, J. C., \& Wang, C. (2014). The challenge of global governance of land grabbing. Globalizations, 10(1), 161-179.

Buainain, A. M., Bonacelli, M. B. M., \& Mendes, C. I. C. (Org.) (2015). Propriedade intelectual e inovações na agricultura. Brasília/Rio de Janeiro: CNPq, Faperj, INCT/PPED, IdeiaD.

Canuto, S. (s/d). Regularização fundiária na Amazônia Legal: contexto, avanços e desafios. Brasil: INCRA. Disponível em: https://www2.camara.leg.br/atividade-legislativa/comissoes/. Acesso em: 8 fev. 2019.

Carvalho, V., \& Tura, L. (2006). A expansão do monocultivo de soja em Santarém e Belterra: injustiça ambientale ameaça à segurança alimentar. FASE-Amazônia.

CNT - Confederação Nacional do Transporte. (2020). Anuário CNT do Transporte: estatísticas consolidadas. Disponível em: http://anuariodotransporte.cnt.org.br/2018/. Acesso em: 14 dez. 2020.

Conab - Companhia Nacional de Abastecimento. (2020). Série Histórica de Produção. Disponível em:http://www.c onab.gov.br. Acesso em: 23 nov. 2020.

Cotula, L., Vermeulen, S., Leonard, R., \& Keeley, J. (2009). Land grab or development opportunity? Agricultural investment and international land deals in Africa. Londres/Roma: IIED/FAO/IFAD.

Embrapa - Empresa Brasileira de Pesquisa Agropecuária. (2004). Reunião de pesquisa de soja da região central do Brasil. Londrina: Embrapa.

Fernández, A. J. C. (2007). Do Cerrado à Amazônia: as estruturas sociais da economia da soja em Mato Grosso. (Tese de doutorado). Universidade Federal do Rio Grande do Sul, PGDR, Porto Alegre.

FNP. (2014). Terra barata leva soja ao extremo Norte. Disponível em: http://www.informaecon-fnp.com/noticia/11 099. Acesso em: 10 mar. 2019.

Guidotti, V., Freitas, F. L., Sparovek, G., Pinto, L. F. G., Hamamura, C., Carvalho, T., \& Cerignoni, F. (2017). Números detalhados do Novo Código Florestal e suas implicações para os PRAs. Sustentabilidade em debate, 5(1), 1-10.

Harvey, D. (2003). O “novo" Imperialismo: acumulação por espoliação. Nova Iorque: Oxford.

Harvey, D. (2005). A Produção Capitalista do Espaço. São Paulo: Anneblume. 
Heredia, B. M. A., Palmeira, M., \& Leite, S. P. (2010). Sociedade e economia do agronegócio. Revista Brasileira de Ciências Sociais, 25, 159-176.

Hope, A., \& Cox, J. (2015). Development Corridors. economic and private sector professional evidence and applied knowledge services. Coffey International Development. Londres: EPS.

IBGE - Instituto Brasileiro de Economia e Estatística. (2020). Banco de dados agregados. Disponível em: http://ww w.sidra.ibge.gov.br. Acesso em: 17 dez. 2020.

Impacto. (2018). Adriano Maraschin. produção de grãos injeta $R \$ 360$ milhões por ano na economia de Santarém e região. Disponível em: https://oimpacto.com.br/2018/10/04/adriano-maraschin-producao-de-graos-injeta-r-360-mil hoes-por-ano-na-economia-de-santarem-e-regiao/ Acesso em: 12 abr. 2019.

Kato, K., Furtado, F., Aleixo Junior, O., \& Siviero, J. (2020). Global financial funds, land grab and the (re)production of inequalities. contribution from Brazil. Roma: ILC.

Leão, S. A. V. (2017). Agronegócio da soja e dinâmicas regionais no Oeste do Pará. (Tese de doutorado). Universidade Federal Rural do Rio de Janeiro, CPDA, Rio de Janeiro.

Levien, M. (2014). Da Acumulação primitiva aos regimes de desapropriação. Sociologia e Antropologia, 4(1), 21-53.

Lima, M. do S. B. de (2008). Políticas públicas e território: uma discussão sobre os determinantes da expansão da soja no sul do Amazonas. (Tese de doutorado). Universidade Federal Rural do Rio de Janeiro, CPDA, Rio de Janeiro.

Nogales, E. G. (2014). Making economic corridors work for the agricultural sector. Agribusiness and Food Industries Series, n. 4. Rome: FAO.

Pinto, E. C. (2013). Dinâmica econômica e regional no Brasil dos anos 2000: efeito China, desconcentração espacial e bloco no poder. Em C. Brandão e H. Siqueira, (orgs.). Pacto federativo, integração nacional e desenvolvimento regional. São Paulo: Fundação Perseu Abramo.

Sassen, S. (2013). Land grabs today: feeding the disassembling of national territory. Globalizations, 10(1), 25-46.

Sassen, S. (2016). Expulsóes: brutalidade e complexidade na economia global. Rio de Janeiro/São Paulo: Editora Paz e Terra.

Sauer, S. (2018). Soy expansion into the agricultural frontiers of the Brazilian Amazon: The agribusiness economy and its social and environmental conflicts. Land Use Policy, 79, 326-338.

Sauer, S., \& Pietrafesa, J. P. (2013). Novas fronteiras agrícolas na Amazônia: expansão da soja como expressão das agroestratégias no Pará. ACTA Geográfica, 7, 245-264.

Scannavino, C. (2018). Santarém sofre pressão para alterar plano diretor na marra, pondo em risco mais uma área de proteção ambiental. Jornalistas livres. Disponível em: https://jornalistaslivres.org/. Acesso em: 10 mar. 2019.

Secex - Secretaria de Comércio Exterior. (2020). Indicadores e Estatísticas de Comércio Exterior. Disponível em: http: //www2.desenvolvimento.gov.br/sitio/secex. Acesso em: 7 dez. 2020.

Smalley, R. (2017). Agricultural growth corridors on the Eastern Seaboard of Africa: an overview. WorkingPaper 1, Agricultural Policy Research in Africa (APRA).

Soares-Filho, B. et al. (2014). Cracking Brazil's forest code. Science, 344(6182), 363-364.

Tavares, J. C. (2016). Eixos: novo paradigma do planejamento regional? Os eixos de infraestrutura nos PPAs nacionais, na IIRSA e na macrometrópole paulista. Caderno Metropolitano, 18(37), 671-695.

USDA - Departamento de Agricultura dos Estados Unidos. (2020). Data and Statistics. Disponível em: http://www .usda.gov/wps/portal/usda/. Acesso em: Março de 2020.

Valbuena, R., \& Cohenca, D. (2006). Reativação da fronteira agrícola e aumento da taxa de desmatamento ao norte da BR-163, nos municípios de Santarém e Belterra, no Pará, Brasil (1999-2004). Agrária, 4, 98-123.

Valentim, E. S. (2018). Análise das estratégias competitivas de Michael Porter na companhia Cargill no Brasil. (Trabalho de conclusão de curso). Universidade Federal do Oeste do Pará, Graduação em Ciências Econômicas, Santarém.

Vianna, P. J. R., Lócio, A. B., \& da Silva Sales, R. (2006). Os Eixos de Integração Nacional e a Integração Regional da Infraestrutura Sul Americana. Fortaleza.

Vieira Filho, J. E. R., \& Gasques, J. G. (Org.) (2016). Agricultura, transformação produtiva e sustentabilidade. Brasília: IPEA. 
Vieira, S. (2018). Aprovação da área portuária do Maicá dá segurança jurídica a empreendedores, diz prefeito de Santarém. Disponível em: https://g1.globo.com/pa/santarem-regiao/noticia/2018/12/14/aprovacao-da-ar ea-portuaria-do-maica-da-seguranca-juridica-a-empreendedores-diz-prefeito-de-santarem.ghtml. Acesso em: 23 mar. 2019.

Wesz Jr., V.J. (2014). O mercado da soja e as relações de troca entre produtores rurais e empresas no Sudeste de Mato Grosso (Brasil) (Tese de doutorado). Universidade Federal Rural do Rio de Janeiro, CPDA, Rio de Janeiro.

White, B., Borras Jr, S. M., Hall, R., Scoones, I., \& Wolford, W. (2012). The New Enclosures: critical perspectives on corporate land deals. Journal of Peasant Studies, 39(3-4), 619-647.

\section{Notas}

* O presente artigo está relacionado a projeto financiado pelo CNPq, Edital Universal de 2016 e 2018.

1. Segundo estudo da Apex-Brasil (2011), a China constituiu um caso paradigmático na medida em que ganhou market share nas exportações de produtos primários e manufaturados intensivos em recursos naturais, ao mesmo tempo em que apresentou perda relativa de importância destes produtos em sua pauta exportadora, não revelando, contudo, uma tendência à primarização.

2. Importante mencionar que em janeiro de 2021 , segundo a $\mathrm{FAO}$, o preço dos alimentos no mundo sofreu um significativo aumento, puxado pelos lacticínios e pelos óleos vegetais.

3. Outros componentes e atividades

4. O Planalto Santareno envolve os municípios de Santarém, Belterra e Mojuí dos Campos, cuja área se caracteriza por solo plano e favorável ao plantio com sistema mecanizado, estando situados às margens de das rodovias BR-163 e PA-370 (Leão, 2017).

5. Vale destacar que Mojuí dos Campos, antes distrito de Santarém, foi o último município emancipado da região Oeste do Pará, em 2012, sendo que em 1 de janeiro de 2013 o seu primeiro prefeito tomou posse. Desta forma, dados desmembrados sobre esse município só começam a ser trabalhados a partir de 2013 (Leão, 2017).

6. Todos os produtores entrevistados eram gaúchos (naturais de Cruz Alta, Santo Ângelo, Erexim e Santa Barbara do Sul).

7. Vale destacar que essa parceria com a CPRM continuou nos mandatos seguintes, do prefeito Lira Maia (1997-2000 e 2001-2004), dando continuidade a estudos sobre a região do Oeste do Pará.

8. Com o crescimento das críticas ambientais à cadeia da soja no Brasil, em 2006 a Associação Brasileira das Indústrias de Óleos Vegetais (Abiove) e a Associação Nacional dos Exportadores de Cereais (ANEC) se comprometeram a não comercializar soja proveniente de áreas que tivessem sido desmatadas dentro da Amazônia Legal. Esse pacto ficou conhecido como Moratória da Soja.

9. Como veremos mais a frente nesse texto, o CAR vem sendo alvo de muitas críticas por se tratar de um cadastro autodeclaratório e que não envolve nenhum tipo de fiscalização ou monitoramento pelo poder público. 